\title{
O niektórych skutkach prawnych i wątpliwościach, jakie rodzą orzeczenia zakresowe Trybunału Konstytucyjnego - uwagi na marginesie wyroku Trybunału Konstytucyjnego z dnia 10 marca 2015 r., sygn. K 29/131
}

\section{Wprowadzenie}

Orzeczenia Trybunału Konstytucyjnego określane mianem wyroków interpretacyjnych lub zakresowych wywoływały i wywołują nadal wiele sporów i emocji. Ich zasadniczym podłożem jest wątpliwość, czy TK w świetle art. 190 Konstytucji Rzeczypospolitej Polskiej ${ }^{2}$ jest uprawniony do wydawania takich wyroków ${ }^{3}$, w których sentencji znajdzie się nie "prosta - zero-jedynkowa" ocena zgodności przedmiotu skargi z danym wzorcem konstytucyjnym, ale zgodność ta lub niezgodność będzie stwierdzona pod pewnymi warunkami. Spór ten, dotyczący

${ }^{1}$ Wyrok Trybunału Konstytucyjnego (dalej „TK” lub „Trybunał”) z 10 III 2015 r., sygn. K 23/13 (Dz.U. poz. 373).

${ }^{2}$ Konstytucja Rzeczypospolitej Polskiej z dnia 2 IV 1997 r. (Dz.U. Nr 78, poz. 483 ze zm.), dalej „Konstytucja RP” lub „ustawa zasadnicza”.

${ }^{3}$ Ponadto także, oczywiście, na podstawie ustrojowej dla jego działalności Ustawy z dnia 25 VI 2015 r. o Trybunale Konstytucyjnym (Dz.U. poz. 1064 ze zm.), dalej „ustawa o TK", a do 30 VIII 2015 r. Ustawy z dnia 1 VIII 1997 r. o Trybunale Konstytucyjnym (Dz.U. Nr 102, poz. 643 ze zm.), dalej „dawna ustawa o TK”. 
mocy wiążącej tego typu rozstrzygnięć dla sądów i innych organów, przeobraził się w pewnym momencie $\mathrm{w}$ otwarty konflikt pomiędzy głównymi uczestnikami dyskursu - przedstawicielami Sądu Najwyższego (SN) oraz $\mathrm{TK}^{4}$ - a w pewnej chwili toczył się na łamach prasy powszechnej ${ }^{5}$.

Współcześnie wyróżnić można rozmaite próby systematyki orzeczeń wydawanych przez TK oraz uchwycenia ich istoty. Przełomowej klasyfikacji dokonał J. Trzciński, który poszerzył dychotomiczny podział orzeczeń Trybunału o zgodności albo niezgodności przedmiotu kontroli z Konstytucją RP. Wyróżnił on dwa podstawowe rodzaje orzeczeń: o zgodności bądź niezgodności z Konstytucją RP danego przedmiotu kontroli, dalej natomiast stwierdził, że istnieją jeszcze takie orzeczenia, które zgodność albo niezgodność z ustawą zasadniczą przedmiotowi kontroli przyznają pod warunkiem jego odpowiedniego rozumienia; uznają zgodność lub niezgodność z ustawą zasadniczą określonego przepisu w odpowiednim zakresie jego stosowania ${ }^{6}$. Klasyfikacja ta stała się podłożem do dalszych badań. Współcześnie autorzy wyróżniają przede wszystkim wyroki proste (klasyczne), interpretacyjne oraz zakresowe $^{7}$. Spotkać się można także z rozróżnieniem na orzeczenie aplikacyjne, reanimacyjne, pozornie zakresowe prawotwórcze, jak i pozornie zakresowe interpretacyjne ${ }^{89}$.

Przystępując do dalszych rozważań w przedstawionym przedmiocie, konieczne staje się uprzednie ukazanie dystynkcji pojęciowej

${ }^{4}$ Uchwała SN z 17 XII 2009 r., sygn. III PZP 2/09, OSNC 2010, nr 7-8, poz. 97; postanowienie SN z 29 IV 2010 r., sygn. IV CO 37/09, OSNC 2010, nr 12, poz. 166; wyrok TK z 27 X 2010 r., sygn. K 10/08 (Dz.U. Nr 205, poz. 1364).

${ }^{5}$ M. Safjan, Interpretacja a kontrola konstytucyjności, „Rzeczpospolita” 29 XII 2003, nr 3112 .

${ }^{6}$ J. Trzciński, Orzeczenia interpretacyjne Trybunału Konstytucyjnego, "Państwo i Prawo" 2002, z. 1, s. 3-4.

${ }^{7}$ Przykładowo, K. Gonera i E. Łętowska dokonały podziału wyroków TK według interesującego kryterium w postaci ich wpływu na strukturę tekstu prawnego, a zatem na takie, które dotyczą konstytucyjności całego przepisu (jednostki redakcyjnej tekstu prawnego) oraz jego fragmentu, zob. K. Gonera, E. Łętowska, Artykuł 190 Konstytucji i jego konsekwencje w praktyce sadowej, „Państwo i Prawo” 2003, z. 9, s. 3-4.

${ }^{8}$ Zob. Prawo konstytucyjne, pod red. Z. Witkowskiego, Toruń 2011, s. 521. Przykładem wyroku pozornie zakresowego interpretacyjnego jest wyrok TK z 13 III 2014 r., sygn. P 38/11 (Dz.U. poz. 376).

${ }^{9} \mathrm{~W}$ tym zakresie zob. opracowanie: D. Nowicki, Miejsce orzeczeń interpretacyjnych w orzecznictwie Trybunału Konstytucyjnego, „Państwo i Prawo” 2012, z. 10, s. 48 n., którego autor przystępnie zreferował m.in. najważniejsze koncepcje oraz klasyfikacje orzeczeń trybunalskich. 
zachodzącej między przepisem prawnym a normą prawną ${ }^{10}$. Przepisem prawnym jest podstawowa jednostka redakcyjna aktu normatywnego ${ }^{11}$. Norma prawna to - w najprostszym ujęciu - wypowiedź dyrektywalna, która określonemu adresatowi, w pewnych okolicznościach nakazuje lub zakazuje określony sposób zachowania. Normy prawne są odtwarzane z przepisów prawnych. Relację zachodzącą między przepisem a normą prawną można przyrównać do relacji zachodzącej między tworzywem a uzyskanym $\mathrm{z}$ niego produktem ${ }^{12}$. $Z$ tego zatem powodu za prawo (istniejące i oddziałujące na życie ludzi) uznaje się zbiór norm prawnych obowiązujących w określonym miejscu i czasie. Zbiór ten jest wewnętrznie uporządkowany, spójny i zupełny. $W$ tym zatem ujęciu wyrok zakresowy, o którym w niniejszym tekście będzie mowa, nie jest z pewnością tworzywem ani też wytworem końcowym. Wytworem jest bowiem obowiązująca norma prawna zastosowana przy formułowaniu indywidualnego rozstrzygnięcia, a wyrok zakresowy TK co najwyżej określa, jakie elementy w zrekonstruowanej normie znaleźć się mogą albo nie (ewentualnie powinny się znaleźć), odnosząc się do zakresowo określonych elementów normatywnych przepisu prawnego w sposób pozytywny albo negatywny ${ }^{13}$.

Przy takim rozumieniu prawa, zdając sobie sprawę, że pomiędzy tworzywem a wytworem zachodzi proces wykładni będący czynnością intelektualna, trudno jednoznacznie przesądzić, jakie jest miejsce tych orzeczeń Trybunału, które nie mają tzw. "prostych skutków”, czyli nie derogują określonej jednostki tekstu prawnego. Prosty wyrok powoduje bowiem, że ze względu na określony wzorzec konstytucyjny przepis prawny (będący wytworem określonego faktu prawotwórczego) traci moc. Nie wnikając $w$ istotę tego teoretycznoprawnego zagadnienia, tj. tego, jakie jest miejsce orzeczeń nieprostych TK w obrębie

${ }^{10}$ Z. Ziembiński, Przepis prawny a norma prawna, „Ruch Prawniczy, Ekonomiczny i Socjologiczny" 1960, z. 1, s. 110 i n.

${ }^{11}$ Jednostki te aktualnie wyznaczają $§ 54$ oraz $\S 124$ ust. 1 Rozporządzenia Prezesa Rady Ministrów z dnia 20 VI 2002 r. w sprawie "Zasad techniki prawodawczej" (Dz.U. Nr 100, poz. 908 ze zm.) i są nimi: artykuł (dla ustaw) i paragraf (dla rozporządzeń).

12 J. Mikołajewicz, Orzeczenia zakresowe i interpretacyjne Trybunału Konstytucyjnego jako przejaw kryzysu legitymizacji legalnej, w: Normalność i kryzys. Jedność czy różnorodność, pod red. J. Oniszczuka, Warszawa 2010, s. 232.

${ }^{13}$ Trybunał Konstytucyjny dokonuje tego w sposób pozytywny, posługując się zwrotami: „w zakresie, w jakim dotyczy”, "w zakresie, w jakim odnosi się do", a negatywny, stosując formuły: „w zakresie, w jakim wyklucza”, „w zakresie, w jakim wyłącza”. Ewentualnie możliwe są wyroki zakresowe dotyczące pominięcia prawodawczego i wówczas spotyka się sformułowania: „w zakresie, w jakim pomija”, „w zakresie, w jakim nie uwzględnia”. 
rozwiniętej, normatywnej koncepcji źródeł prawa ${ }^{14}$, najbezpieczniej obecnie przyjąć, że orzeczenie zakresowe współwyznacza treść odkodowanej normy prawnej z tego oto powodu, że jego sentencjom przysługuje przymiot powszechnej obowiązywalności - a zatem w państwie prawa w procesie stosowania prawa (poprzedzonym niezbędną czynnością w postaci ustalenia treści normy prawnej) musi być ono brane pod uwagę.

\section{Charakterystyka wyroku Trybunału Konstytucyjnego z 10 marca 2015 r., sygn. K 29/13}

W dniu 10 marca 2015 r. Trybunał Konstytucyjny orzekł, że art. 1 ust. 1 i 3 Ustawy z dnia 29 lipca 2005 r. o przekształceniu prawa użytkowania wieczystego $\mathrm{w}$ prawo własności nieruchomości ${ }^{15} \mathrm{~W}$ zakresie, $\mathrm{w}$ jakim przyznaje uprawnienie do przekształcenia prawa użytkowania wieczystego w prawo własności osobom fizycznym i prawnym, które nie miały tego uprawnienia w dniu wejścia w życie Ustawy z dnia 28 lipca 2011 r. o zmianie ustawy o gospodarce nieruchomościami oraz niektórych innych ustaw $^{16}$, jest niezgodny z art. 2 Konstytucji RP, a ponadto:

a) w zakresie, $w$ jakim dotyczy nieruchomości stanowiących własność jednostek samorządu terytorialnego, jest niezgodny z art. 165 ust. 1 Konstytucji RP,

b) w zakresie, w jakim dotyczy nieruchomości stanowiących własność Skarbu Państwa, nie jest niezgodny z art. 165 ust. 1 oraz art. 167 ust. 1 i 2 Konstytucji RP ${ }^{17}$.

${ }^{14}$ Z. Ziembiński, Podstawowe problemy prawoznawstwa, Warszawa 1980, s. 245 i n. W ramach tej koncepcji wyrok zakresowy (a już tym bardziej interpretacyjny), jeśli nie jest wykładnią formalna, czyli zespołem czynności interpretacyjnych realizowanych przez jakiś podmiot, którego rezultaty interpretacji są zawsze silniejsze od wykładni merytorycznej dokonywanej przez inne podmioty, i są one wówczas wiążące (do czego jednakże potrzebna jest norma kompetencyjna) - to jest być może pewną powszechnie obowiązująca - ze względu na art. 190 ust. 1 Konstytucji RP - regułą egzegezy. W takim zatem ujęciu byłaby to reguła egzegezy nakazująca z istniejącym faktem prawotwórczym w sensie apragmatycznym (obowiązującym w postaci nieprzekształconej, nawet po wyroku zakresowym TK, przepisem prawnym) wiązać określoną normę prawna, o takich jej jednak elementach, które są zgodne z Konstytucją RP (tj. w ściśle w sentencji wyroku TK wyznaczonym zakresie).

${ }^{15}$ Tekst jedn. Dz.U. 2012, poz. 83 ze zm., dalej „ustawa o przekształceniu”.

${ }^{16}$ Dz.U. Nr 187, poz. 1110, dalej „nowela z 2011 r." lub „ustawa nowelizująca z 2011 r.”.

${ }^{17}$ Wskazany wyrok TK został ogłoszony w Dzienniku Urzędowym 17 III 2015 r. 
Powyższy wyrok został sprostowany postanowieniem Trybunału Konstytucyjnego z 25 marca 2015 r. w ten sposób, że wyrażenie złożone "W dniu wejścia w życie ustawy" zastąpiono wyrażeniem "przed wejściem w życie ustawy"18.

Przedmiotowy wyrok jest interesujący z kilku względów. Po pierwsze, jest on przykładem orzeczenia powziętego wskutek wniosku podmiotów posiadających tzw. szczególną legitymację procesową - organów stanowiących jednostek samorządu terytorialnego - wynikająca z art. 191 ust. 1 pkt 3 i ust. 2 Konstytucji RP. Legitymacja szczególna polega na tym, że organy te mogą składać wnioski inicjujące postępowanie przed Trybunałem, ale w sprawach objętych swoim zakresem działania. Przesłankę tę ujmować należy (interpretować) ściśle, a badanie jej zaistnienia jest intelektualnym procesem prowadzącym do konkretnego rezultatu, a mianowicie wskazania przepisu, który zalicza normę lub jej zakres, objęte zarzutem niekonstytucyjności, do zakresu działania podmiotu inicjującego postępowanie ${ }^{19}$. W przywołanym wyroku TK przyjąl, że jednostka samorządu terytorialnego posiada legitymację do zaskarżenia przepisów art. 1 ust. 1 i ust. 3 ustawy o przekształceniu także w zakresie odnoszącym się do nieruchomości Skarbu Państwa, gdyż „postępowanie zainicjowane przez podmioty o legitymacji szczególnej - jakimi są jednostki samorządu terytorialnego - ma charakter kontroli abstrakcyjnej i zmierza do ochrony interesu publicznego, a nie tylko interesu konkretnego wnioskodawcy lub interesu komunalnego w ogólności. Przenosząc ten pogląd na stan faktyczny niniejszej sprawy, należy uznać, że sformułowane przez wnioskodawców zarzuty sprzeczności zaskarżonej regulacji z art. 2 Konstytucji RP dotyczą zarówno przekształcenia prawa użytkowania wieczystego tych nieruchomości, których właścicielami są jednostki samorządu terytorialnego, jak i tych nieruchomości, których właścicielem jest Skarb Państwa"20. Tak podjętą decyzję uzasadniano również w ten sposób, że ograniczenie stwierdzenia niekonstytucyjności do użytkowników wieczystych nieruchomości gminnych, pozostawiając

${ }^{18}$ Postanowienie TK z 25 III 2015 r., sygn. K 29/13 (Dz.U. poz. 524). To postanowienie zostało ogłoszone w Dzienniku Urzędowym 14 IV 2015 r.

${ }^{19}$ S.J. Jaworski, Uprawnienia podmiotów legitymowanych warunkowo do wszczynania postępowania przed Trybunałem Konstytucyjnym (wybrane problemy), w: Trybunat Konstytucyjny. Księga XV-lecia, pod red. F. Rymarza, A. Jankiewicza, Warszawa 2001, s. 123-133.

${ }^{20}$ Zdanie odrębne sędziego TK Z. Czeszejko-Sochackiego od wyroku TK z 12 IV 2000 r., sygn. K 8/98, OTK ZU 2000, nr 3, poz. 87. 
w mocy "uwłaszczenie" użytkowników wieczystych nieruchomości państwowych, doprowadziłoby do wtórnej niekonstytucyjności, wyrażającej się w odmiennym traktowaniu podmiotów znajdujących się w takiej samej sytuacji prawnej. Trafność przedstawionego rozumowania stanowić może przedmiot samodzielnej glosy.

Przytoczony wyrok wysuwa jednak - co najważniejsze - na pierwszy plan co najmniej trzy problemy teoretycznoprawne dotyczące wyroków zakresowych jako takich.

\section{Skutki omyłki pisarskiej w wyroku zakresowym Trybunału Konstytucyjnego}

Po pierwsze, wyrok ten w pierwotnej swej formie był opatrzony omyłką pisarska, która została sprostowana w trybie art. 73 ust. 1 dawnej ustawy o TK. Za zagadnienie interesujące zarówno pod względem teoretycznoprawnym, jak i praktycznym uznać należy kwestię wpływu omyłki pisarskiej zawartej w orzeczeniu Trybunału Konstytucyjnego niebędącym wyrokiem prostym na procesy stosowania prawa. $W$ tym celu przypomnieć należy, że orzeczenie TK uzyskuje moc obowiązującą - w myśl art. 190 ust. 2 i 3 Konstytucji RP - z chwilą jego ogłoszenia w Dzienniku Urzędowym ${ }^{21}$. Orzeczenia trybunalskie mogą mieć postać wyroku albo postanowienia. Postanowienia wydawane na zasadzie art. 73 ust. 1 dawnej ustawy o TK zapadały na posiedzeniu niejawnym $\mathrm{w}$ celu sprostowania zawartych w orzeczeniu lub w jego uzasadnieniu niedokładności, błędów pisarskich lub rachunkowych albo innych oczywistych omyłek. Obecnie aspekt powyższy reguluje art. 106 ustawy o TK. Nie ulega wątpliwości, że postanowienia takie - będące rodzajem orzeczenia - swój byt prawny rozpoczynają od momentu ich podpisania

${ }^{21}$ Wprawdzie w ust. 2 ustawodawca posłużył się wyrażeniem "podlegają niezwłocznemu ogłoszeniu w organie urzędowym, w którym akt normatywny był ogłoszony", a w ust. 3 - wskazującym, kiedy następuje skutek prawny w postaci uzyskania przez orzeczenie TK mocy obowiązującej - czytamy: „Orzeczenie Trybunału Konstytucyjnego wchodzi w życie z dniem ogłoszenia", jednak - jak słusznie wyjaśniła M. Florczak-Wątor jest to celowy zabieg prawodawcy i efekt zastosowanej przez niego techniki dążącej do skrótowości tekstu prawnego. Reasumując, „[d]opiero z chwilą ogłoszenia w organie publikacyjnym, a nie z chwilą ogłoszenia ustnie na sali rozpraw, orzeczenie Trybunału Konstytucyjnego uzyskuje moc powszechnie obowiązującą" (M. Florczak-Wątor, Orzeczenia Trybunatu Konstytucyjnego i ich skutki prawne, Poznań 2006, s. 77-82). 
( $\$ 50$ ust. 1 regulaminu Trybunału Konstytucyjnego ${ }^{22}$ ). Skoro postanowienia takie nie podlegają ogłoszeniu na posiedzeniu jawnym, to nie ulega wątpliwości, że wiążą one erga omnes - podobnie jak sam wyrok od momentu ich ogłoszenia w Dzienniku Urzędowym ${ }^{23}$.

Dalszą część rozważań na temat sygnalizowanego problemu rozpocząć należy od stwierdzenia, że sprostowana przez TK omyłka wcale nie była oczywista. Nie było również tak, iż "[s]formułowanie zawarte w pierwotnym kształcie sentencji oznaczałoby, że wyrok Trybunału Konstytucyjnego pozbawiony jest logicznego sensu, gdyż odnosi się do nieistniejących stanów faktycznych, czy też - ma za przedmiot pusty zbiór desygnatów" ${ }^{\prime 24}$. Wskazać należy, że pod rządami ustawy o przekształceniu sprzed "derogacji” trybunalskiej dokonanej wyrokiem z 10 marca 2015 r. w orzecznictwie sądowoadministracyjnym istniał spór dotyczący tego, jak należy rozumieć art. 1 ust. 1 i $3 \mathrm{w}$ świetle ust. $1 \mathrm{~b}$ ustawy o przekształceniu. Część sądów administracyjnych uznawała, że następca prawny użytkownika wieczystego, będącego 13 października 2005 r. państwową lub samorządową osobą prawną, może wystąpić z wnioskiem o przekształcenie prawa użytkowania wieczystego nieruchomości w prawo własności ${ }^{25}$. Druga grupa sądów administracyjnych uważała inaczej, a mianowicie, że następca prawny takiego podmiotu jest pozbawiony prawa do żądania przekształcenia, skoro takiego prawa

${ }^{22}$ Uchwała Zgromadzenia Ogólnego Sędziów Trybunału Konstytucyjnego z 15 IX 2015 r. w sprawie Regulaminu Trybunału Konstytucyjnego (M.P. poz. 823). W poprzednio obowiązującym regulaminie, przyjętym uchwałą Zgromadzenia Ogólnego Sędziów Trybunału Konstytucyjnego z 3 XI 2006 r. w sprawie Regulaminu Trybunału Konstytucyjnego (M.P. Nr 72, poz. 720), aspekt ten uregulowany był w § 51 ust. 1.

${ }^{23} \mathrm{~W}$ przypadku postanowień TK trudno zatem o podobne wątpliwości, jakie zachodzą w przypadku wyroków, tj. odnoszących się do tego, jakie są losy i skutki prawne orzeczeń pomiędzy ich ogłoszeniem uczestnikom na rozprawie a chwilą ich promulgacji, zob. M. Florczak-Wątor, op. cit., s. 78-79.

${ }^{24}$ Ponadto, jak podaje Trybunał w uzasadnieniu postanowienia z 25 III 2015 r., marginalnie wskazać należy, że sytuacja taka nie oznaczałaby nawet, iż wyrok pozbawiony byłby logicznego sensu, lecz - co najwyżej - iż odnosiłby się do zbioru pustego, a zatem do zbioru niezawierającego w sobie żadnych elementów.

${ }^{25}$ Wyrok Wojewódzkiego Sądu Administracyjnego (WSA) w Gliwicach z 31 I 2013 r., sygn. II SA/Gl 993/12; wyrok WSA w Gdańsku z 15 X 2013 r., sygn. II SA/Gd 496/13; wyrok WSA w Krakowie z 8 X 2013 r., sygn. II SA/Kr 803/13; wyroki WSA w Poznaniu: z 29 V 2014 r., sygn. IV SA/Po 305/14; z 23 III 2014 r., sygn. IV SA/Po 306/14; z 25 IX 2014 r., sygn. II SA/Po 690/14 (wszystkie przywoływane wyroki sądów administracyjnych dostępne w Centralnej Bazie Orzeczeń Sądów Administracyjnych, http://orzeczenia. nsa.gov.pl/, dostęp: 7 V 2016). 
nie posiadał jego poprzednik prawny ${ }^{26}$. Pogląd drugi znalazł swoje odzwierciedlenie także $\mathrm{w}$ doktrynie ${ }^{27}$.

Zważając na powyższe, nietrudno zauważyć, że adresat wyroku z 10 marca 2015 r. znający istotę scharakteryzowanego sporu, świadomy, iż nie każdy wyrok, który posługuje się formułą "w zakresie”, jest wyrokiem zakresowym, uznać mógł - w momencie wejścia w życie tegoż orzeczenia z dniem ogłoszenia, czyli 17 marca 2015 r. - iż wyrok ten $\mathrm{w}$ początkowej swej części jest $\mathrm{w}$ istocie interpretacyjny. Oto bowiem można było przyjąć - nie zaznajomiwszy się z informacjami medialnymi na temat tego wyroku - że osoby będące następcami prawnymi osób wymienionych w art. 1 ust. 1 b ustawy o przekształceniu nie maja, w ocenie TK, uprawnienia do domagania się przekształcenia prawa użytkowania wieczystego w prawo własności ze względu na niezgodność takiej normy prawnej z powołanym wzorcem konstytucyjnym - zasadą sprawiedliwości społecznej ${ }^{28}$. W momencie wejścia w życie ustawy nowelizującej z 2011 r. istniały bowiem takie osoby fizyczne lub prawne, które nie miały prawa do przekształcenia prawa użytkowania wieczystego w prawo własności. Tymi osobami byli właśnie owi „następcy prawni” tych użytkowników wieczystych, których nieruchomości na mocy art. 1 ust. 1 b ustawy o przekształceniu były wyłączone $\mathrm{z}$ administracyjnoprawnego trybu przekształcenia. $Z$ tej zatem przyczyny adresat przedmiotowego wyroku, uwzględniając pierwotny kształt słowny jego sentencji, mógłby przyjać, że rzeczywistą intencją Trybunału było stwierdzenie niekonstytucyjności rozumienia art. 1 ust. 1 i 3 ustawy o przekształceniu, a nie - określonego po sprostowaniu omyłki pisarskiej - zakresu normy prawnej. Innymi słowy, można było sądzić, że Trybunał orzekł, jakie rozumienie art. 1 ust. 1 i ust. 3 ustawy o przekształceniu jest niezgodne z Konstytucja, a mianowicie takie, które przyznaje następcom prawnym użytkowników wieczystych,

${ }^{26}$ Wyroki WSA w Poznaniu: z 19 III 2014 r., sygn. II SA/Po 1324/13; z 19 III 2014 r., sygn. II SA/Po 1325/13; wyroki WSA w Warszawie: z 22 I 2013 r., sygn. I SA/Wa 1713/12; z 11 VI 2014 r., sygn. I SA/Wa 2438/13.

${ }^{27}$ M. Gdesz, Komentarz do ustawy o przekształceniu prawa użytkowania wieczystego w prawo własności, Zielona Góra 2011, s. 52-53.

${ }^{28}$ Mowa tutaj o komunikatach prasowych oraz publikowanych na stronie internetowej http://trybunal.gov.pl/. Trudno uznać, że obowiązkiem organu stosującego prawo jest znajomość komunikatów prasowych dotyczących rozpraw w TK. Komunikaty takie nie mają nawet - jak chociażby uzasadnienia do projektów ustaw, wykorzystywane tak chętnie przez prawników praktyków w celu odnalezienia intencji prawodawcy - cechy dokumentu urzędowego, nie wiadomo, kto je sporządza i odpowiada za ich rzetelność. 
o jakich mowa w art. 1 ust. 1 b ustawy o przekształceniu, uprawnienie do domagania się przekształcenia prawa użytkowania wieczystego w prawo własności. Taka interpretacja omawianego wyroku TK byłaby tym bardziej uzasadniona, skoro nie istnieje domniemanie omyłki pisarskiej w akcie wydanym przez dowolny organ władzy publicznej, a zatem adresat orzeczenia Trybunału nie miał podstaw, by sądzić, że wydany wyrok nie odzwierciedla należycie jego intencji. Po drugie, oceniając ów aspekt $z$ perspektywy organów stosujących prawo, a nie adresatów systemu prawnego, do jakich należą przede wszystkim obywatele, nie istnieje powinność oczekiwania na uzasadnienie orzeczenia Trybunału przed załatwieniem sprawy indywidualnej i konkretnej ${ }^{29}$. Stąd nietrudno już o wniosek, że mogło dojść do sytuacji rozstrzygnięcia sprawy indywidualnej na podstawie takiego właśnie rozumienia wyroku z 10 marca 2015 r. ${ }^{30}$, tj. zakładającego, że wyrok ten był w istocie interpretacyjny.

Na tle tak określonego możliwego ciągu skutkowego po wyroku TK z 10 marca 2015 r. wyłaniają się dwa pytania, z których jedno pozostanie na razie bez odpowiedzi. Czy orzeczenie TK podlega interpretacji, a jeśli tak, to na jakich regułach interpretacja taka powinna się zasadzać? Jaki jest wpływ postanowienia prostującego omyłkę pisarską w wyroku TK dla sprawy, która przed sprostowaniem została ostatecznie załatwiona w sposób odmienny, niż było to intencją TK, co stało się zrozumiałe w pełni dopiero po sprostowaniu omyłki pisarskiej i publikacji uzasadnienia wyroku w zbiorze orzeczeń?

Odpowiedź na drugie pytanie nie jest zadaniem łatwym ani zasadniczym celem niniejszego opracowania. Można jedynie spostrzec, że żaden z tych problemów nie wystąpiłby w przypadku wyroków trybunalskich mających charakter "prosty", czyli eliminujących określony

${ }^{29}$ Nie można zapominać, że w postępowaniu administracyjnym obowiązuje - ze względu na art. 12 \& 1 Ustawy z dnia 14 VI 1960 r. Kodeks postępowania administracyjnego (tekst jedn. Dz.U. 2016, poz. 23) zasada szybkości postępowania. Chociażby ta zatem zasada - w przypadku derogacji trybunalskiej - może implikować dążenie organów administracji publicznej do załatwienia zawisłej sprawy przed sporządzeniem i ogłoszeniem uzasadnienia (którego sporządzenie nie dość, że nastąpić może w terminie odległym w stosunku do daty wydania orzeczenia - dawna ustawa o TK przewidywała w art. 71 ust. 3 miesięczny termin instrukcyjny na wykonanie takiej czynności - to jeszcze ono samo publikowane jest w Dzienniku Urzędowym w terminie odległym).

${ }^{30}$ Zwłaszcza że od ogłoszenia wyroku w Dzienniku Urzędowym do jego sprostowania upłynęło 12 dni, zaś do momentu ogłoszenia (wejścia w życie) postanowienia prostującego minęło 28 dni. 
przepis prawny (całą jednostkę redakcyjną) z tekstu prawnego ${ }^{31}$. Próba udzielenia odpowiedzi na pytanie pierwsze nastąpi w dalszej części niniejszego opracowania.

\section{Odżycie normy prawnej jako pośrednia konsekwencja wyroku zakresowego Trybunału Konstytucyjnego}

Wyrok TK z 10 marca 2015 r. jest interesujący ze względu na skutek jego zakresowości powodujący - pośrednio - efekt odżycia normy prawnej o zakresie niegdyś obowiązującym. Zagadnienie odżycia norm prawnych nie jest wyłącznie teoretyczne ${ }^{32}$. Dotychczas skutek ten przypisywano takim wyrokom trybunalskim, przedmiotem kontroli których był przepis zmieniający bądź uchylający. Ich derogacja (eliminacja) z systemu prawnego implikować miała skutek ex lege w postaci reaktywowania przepisów znowelizowanych bądź uchylonych przepisami uznanymi za niekonstytucyjne wyrokiem Trybunału Konstytucyjnego. Wobec takich skutku wyroków Trybunału stawiane są zarzuty, że wkraczają one w kompetencje ustawodawcze parlamentu ${ }^{33}$. Usprawiedliwieniem dla jej stosowania ma być jednak argument o "minimalizacji” skutków działań organów tworzących prawo i fakt, że gdyby wziąć pod uwagę, iż "W przypadku przepisów uchylających lub zmieniających samo tylko pozbawienie ich mocy obowiązującej bez jednoczesnego «odżycia» przepisów uchylonych mogłoby w pewnych sytuacjach prowadzić do usankcjonowania skutków działań prawodawczych sprzecznych z Konstytucją. Orzeczenie Trybunału Konstytucyjnego nie zmieniałoby

${ }^{31}$ Trudno wszak wyobrazić sobie takie orzeczenie TK, w którego sentencji znalazłaby się omyłka pisarska polegająca na stwierdzeniu niezgodności z Konstytucją nie tego przepisu, który był przedmiotem kontroli. Zwłaszcza że - jak pokazuje praktyka i co wynika z tradycji oraz z art. 325 Ustawy z dnia 17 XI 1964 r. Kodeks postępowania cywilnego (tekst jedn. Dz.U. 2014, poz. 101 ze zm.) - informacja o przedmiocie kontroli znajduje się w dwóch miejscach w strukturze wyroku TK: w części nazywanej tradycyjnie rubrum (chodzi tu o krótką charakterystykę wniosku inicjującego kontrolę, z której tradycyjnie wynika, co skarżył wnioskodawca - a co jest elementem tzw. komparycji wyroku), i w samym tenorze (formule).

${ }^{32}$ Koncepcja "odżycia normy prawnej” jako skutku orzeczenia przez Trybunał Konstytucyjny o niezgodności z ustawą zasadniczą przepisu zmieniającego bądź uchylającego pojawia się zwłaszcza w pracach: A. Mączyński, Kontrola konstytucyjności przepisów uchylajacych i zmieniających, w: Trybunat Konstytucyjny..., s. 157; M. Florczak-Wątor, op. cit., s. 142 i $n$.

${ }^{33}$ R. Hauser, J. Trzciński, Prawotwórcze znaczenie orzeczeń Trybunału Konstytucyjnego w orzecznictwie Naczelnego Sądu Administracyjnego, Warszawa 2010, s. 122-129. 
bowiem w żaden sposób stanu prawnego; norma uchylona w sposób niezgodny z Konstytucją nadal nie obowiązywałaby"34. Nie wnikając $w$ tę koncepcję, należy zauważyć, że jej fundamentem jest podstawowe założenie, a mianowicie, iż skoro moc obowiązującą $w$ danym momencie stracił przepis nowelizujący, to od tego dnia aktualny kształt słowny przedmiotowego fragmentu aktu normatywnego jest taki, jaki byłby on, gdyby nie było tej nowelizacji. $W$ takim natomiast ujęciu tworzywem, z którego rekonstruowana jest norma prawna, są przepisy o dawnym brzmieniu. Pomijając zatem problemy intertemporalne związane z ustalaniem aneksów czasowych zakresów zastosowania poszczególnych norm prawnych ${ }^{35}$ (tj. tych, których tworzywem są przepisy dawne, i tych, które zdekodowane zostały na podstawie przepisów przez jakiś czas znowelizowanych), ze względu na performatywność aktu derogacji ${ }^{36}$, np. samego jedynie przepisu nowelizującego, jego konsekwencją nieuchronną musi być "odżycie" poprzedniego kształtu słownego przepisu prawnego (a co za tym idzie, normy lub norm prawnych).

Wyrok Trybunału z 10 marca 2015 r. wywołał w pewnym sensie efekt "odżycia norm”, ale w sposób niebezpośredni. Efekt ten wynika z treści rozstrzygnięcia, którego zrozumienie jest możliwe dzięki uzasadnieniu orzeczenia. Jak czytamy w tymże uzasadnieniu, "[s]kutkiem stwierdzenia przez Trybunał zakresowej niezgodności art. 1 ust. 1 i 3 ustawy o przekształceniu z 2005 r. z art. 2 Konstytucji oraz - w odniesieniu do nieruchomości stanowiących własność jednostek samorządu terytorialnego - z art. 165 ust. 1 Konstytucji jest brak podstawy prawnej dla przekształcenia, w trybie administracyjnym, prawa użytkowania wieczystego w prawo własności. Skutek ten jest ograniczony tylko do tych sytuacji, w których - do dnia wejścia w życie ustawy nowelizującej z 2011 r., czyli na podstawie wcześniej obowiązujących przepisów użytkownikowi wieczystemu nie przysługiwało uprawnienie do żądania

${ }^{34}$ Fragment uzasadnienia postanowienia Trybunału Konstytucyjnego z 21 III 2000 r., sygn. K 4/99, OTK ZU 2000, nr 2, poz. 65.

${ }^{35}$ Wyrażenie "aneks czasowy zakresu zastosowania normy prawnej” użyte tutaj zostało w rozumieniu przedstawionym przez J. Mikołajewicza w pracy pod jego redakcją Problematyka intertemporalna w prawie. Zagadnienia podstawowe. Rozstrzygnięcia intertemporalne. Geneza, funkcje, aksjologia, Warszawa 2015, s. 3-17, a zatem z uwzględnieniem tego, że obowiązywanie normy prawnej jest kategorią historyczną, okolicznością, którą wyrazić można okolicznikiem czasu, odpowiadającym na pytania: „kiedy?”, "od kiedy?”, "do kiedy?", ,jak długo?".

${ }^{36}$ A w zasadzie najczęściej jednak abrogacji. 


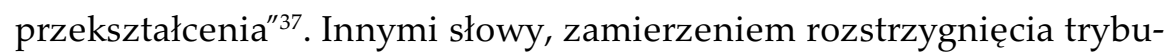
nalskiego było, aby zakres zastosowania normy prawnej wynikającej $\mathrm{z}$ art. 1 ust. 1 i ust. 3 ustawy o przekształceniu prawa użytkowania wieczystego - która wskazywała, kto (jaki podmiot), kiedy (w jakich okolicznościach) i czego może żądać (przekształcenia prawa użytkowania wieczystego) od właściwego rzeczowo i miejscowo organu administracji publicznej (o czym jest mowa w innych przepisach mających charakter uzupełniający $\left.{ }^{38}\right)$ - dostosować do takiego, jaki obowiązywał przed wejściem w życie ustawy nowelizującej z 2011 r. Powyższe oznacza zatem, że norma prawna, którą można zrekonstruować na podstawie aktualnie obowiązującego art. 1 ust. 1 i 3 ustawy o przekształceniu, z uwzględnieniem wskazań Trybunału, jest w zasadzie taka, jaka obowiązywała przed wejściem w życie art. 2 pkt 1 lit. a i d noweli z 2011 r. Oto bowiem art. 2 pkt 1 lit. a i d noweli z 2011 r. zmodyfikowały w taki sposób kształt słowny przedmiotu kontroli trybunalskiej (art. 1 ust. 1 i 3 ustawy o przekształceniu), że wyinterpretować można było na ich podstawie normę prawną uznaną w określonym zakresie przez Trybunał Konstytucyjny za niezgodną z art. 2 Konstytucji RP. Innymi słowy, kształt słowny art. 1 ust. 1 i 3 ustawy o przekształceniu przed wejściem w życie noweli z 2011 r. był taki, iż zakodowane w nim normy prawne nie były, w określonym przez Trybunał zakresie, niezgodne z Konstytucją RP.

Twierdzenie, że wyrok zakresowy może spowodować odżycie norm prawnych w brzmieniu sprzed określonej nowelizacji, wzmacnia dodatkowy argument. Oto bowiem w praktyce prawniczej podstawowym krokiem w dowolnym procesie wykładni prawa (w sensie pragmatycznym) jest wykonanie czynności polegającej na ustaleniu aktualności obowiązywania przepisu prawnego i jego kształtu słownego ${ }^{39}$. W sytuacji takiej jak analizowana - gdy derogacja trybunalska przybrała postać zakresową ${ }^{40}$, a zatem kształt słowny przepisu nie uległ

${ }^{37}$ Ten kierunek wykładni orzeczenia Trybunału z 10 III 2015 r. umacnia także analiza stenogramu z rozprawy, a w szczególności fragment, w którym sędzia sprawozdawca zadawał wnioskodawcom pytania, s. 27-31, http://otk.trybunal.gov.pl/orzeczenia/ezd/ sprawa_lista_plikow.asp?syg=K\%2029/13 (dostęp: 22 VI 2015).

${ }^{38}$ M. Zieliński, Wykładnia prawa. Zasady, reguły, wskazówki, Warszawa 2012, s. 111. $\mathrm{W}$ analizowanym przypadku są to art. 3 ust. 1 pkt 1 lub 2 ustawy o przekształceniu.

${ }^{39}$ Ibidem, s. 317.

${ }^{40}$ Trzeba odróżniać wyrok zakresowy od wyroku częściowego. Ten pierwszy jest jak wspomniano - ingerencją w element normatywny przepisu prawnego i w zasadzie współwyznacza on, mocą swej powszechnie obowiązującej sentencji, treść normy prawnej. Wyrok częściowy natomiast dotyczy takiej sytuacji, gdy TK wyodrębnia z przepisu 
zmianie - konieczne jest precyzyjne ustalenie zakresu stwierdzonej niezgodności. W niniejszej sprawie prawidłowe, tj. uwzględniające uzasadnienie trybunalskie, odczytanie tego zakresu prowadzi do wniosku, że w celu ustalenia "aktualnej” postaci słownej ustawy o przekształceniu należy przyjąć, iż TK orzekł o niezgodności art. 2 pkt 1 lit. a i d noweli z $2011 \mathrm{r}^{41}$, a tym samym "obowiązującą" postacią słowną art. 1 ust. 1 i 3 ustawy o przekształceniu jest ta sprzed nowelizacji z 2011 r. Przyjęcie takiej fikcji nie dość, że ułatwia - prawnikom praktykom stosowanie prawa w życiu codziennym, to jeszcze umożliwia (lub przynajmniej ułatwia) odtworzenie takiej normy prawnej, której zakres zastosowania nie będzie niezgodny z zakresem wyznaczonym przez Trybunał.

\section{Wykładnia wyroku zakresowego Trybunału Konstytucyjnego}

Ostatni z powodów, dla których rzeczone orzeczenie zakresowe jest interesujące, to fakt, że na podstawie samej tylko jego sentencji nie można dokonać prawidłowych ustaleń, jaki jest zakres niezgodności art. 1 ust. 1 i 3 ustawy o przekształceniu z powołanymi wzorcami konstytucyjnymi, ergo jaki zakres wyinterpretowanej normy prawnej jest "prawidłowy”. Bez sięgnięcia do jego uzasadnienia dojść można do rezultatów niezgodnych z intencją składu orzekającego. Wskazać należy, że w literaturze przedmiotu zauważa się, iż uzasadnienie wyroku

prawnego takie słowo, wyrażenie lub zwrot, których usunięcie z jednostki redakcyjnej jest możliwe. Przykładem takiego orzeczenia jest częściowo zakresowy wyrok Trybunału Konstytucyjnego z 18 IX 2014 r., sygn. K 44/12 (Dz.U. poz. 1327), mocą punktu pierwszego którego uznano, że art. 1 ust. 2 Ustawy z dnia 5 VII 1990 r. Prawo o zgromadzeniach (tekst jedn. Dz.U. 2013, poz. 397 ze zm.), w części zawierającej wyrażenie „co najmniej 15", jest niezgodny z art. 57 w zw. z art. 31 ust. 3 Konstytucji RP.

${ }^{41}$ Aktualny kształt słowny ustawy o przekształceniu nie uległ zmianie i jego art. 1 ust. 1 wciąż stanowi, że osoba prawna może żądać przekształcenia prawa użytkowania wieczystego w prawo własności. Kiedy mowa o „aktualnym” kształcie słownym, chodzi o dążenia do ustalenia nieoficjalnego tekstu tej ustawy uwzględniającego derogację trybunalską. Takim nieoficjalnym tekstem ustawy będzie natomiast aktualny tekst tej ustawy uwzględniający jednak, że w miejscu art. 1 ust. 1 i ust. 3 znajdują się takie przepisy, które obowiązywały przed 9 X 2011 r. Oczywiście, tak "ustalony" tekst prawny stosować należy jedynie jako czynnik pomocniczy w procesach stosowania ustawy o przekształceniu prawa użytkowania wieczystego w prawo własności od 17 III 2015 r. (a w zasadzie - zważając na sprostowanie omyłki pisarskiej postanowieniem z 25 III 2015 r. - od 14 IV 2015 r.). 
TK - jakkolwiek nie ma mocy obowiązującej na zasadzie art. 190 ust. 1 Konstytucji RP, gdyż moc ta odnosi się tylko do sentencji wyroku - służy jako co najwyżej środek poznania przesłanek i argumentów, na których oparto rozstrzygnięcie Trybunału. Uzasadnienie orzeczenia TK nie jest bowiem zdolne do samoistnego wywołania skutków takich, jakie generuje jedynie jego sentencja ${ }^{42}$. Uzasadnieniu wyroku trybunalskiego przysługuje co najwyżej cecha ratio decidendi, gdyż zawiera ono takie zdania, które w sentencji znaleźć się nie mogły, a które stanowić mają jej uzupełnienie i wykładnię ${ }^{43}$. Niemniej jednak trafną uwagę sformułowała M. Florczak-Wątor, a mianowicie: „de lege lata żadnym elementom uzasadnienia orzeczenia TK nie przysługuje moc powszechnie obowiązująca, choć niewątpliwie ich ścisły związek z sentencją stanowi czynnik ułatwiający wykładnię tej ostatniej"44.

Przyjmijmy zatem - na użytek dalszych rozważań - że sytuacją wyjściową dla "zastosowania” wyroku zakresowego Trybunału jest znajomość samej tylko jego sentencji. W pierwszej części opracowania przyjęto, iż wyrok zakresowy - jako że posiada moc powszechnie obowiązującą - współwyznacza treść odkodowywanej normy prawnej z przepisu prawnego objętego kontrolą trybunalską. Wyrok TK nie jest z pewnością powszechnym źródłem prawa w znaczeniu, o jakim mowa w art. 87 ustawy zasadniczej ${ }^{45}$.

Przedmiotem teorii i praktyki wykładni są przepisy prawa ${ }^{46}$. Wyrok zakresowy - a w zasadzie treść jego sentencji - jest de facto wytworem wykładni dokonanej przez sam Trybunał, i to dokonanej przez pryzmat wzorców konstytucyjnych. W takim ujęciu trudno zatem mówić o wy-

42 Wyrok TK z 5 XII 1986 r., sygn. U 5/86, OTK 1986, s. 7-31.

${ }^{43}$ Postanowienie TK z 21 III 2000 r., sygn. K 4/99, OTK ZU 2000, nr 2, poz. 65; wyrok TK z 26 III 2002 r., sygn. SK 2/01 (Dz.U. Nr 37, poz. 353).

${ }^{44}$ M. Florczak-Wątor, op. cit., s. 60-63.

${ }^{45}$ Dla wygody czytelnika zacytujmy go in extenso: „Art. 87. 1. Źródłami powszechnie obowiązującego prawa Rzeczypospolitej Polskiej są: Konstytucja, ustawy, ratyfikowane umowy międzynarodowe oraz rozporządzenia. 2. Źródłami powszechnie obowiązującego prawa Rzeczypospolitej Polskiej są na obszarze działania organów, które je ustanowiły, akty prawa miejscowego".

${ }^{46}$ Wykładnia może mieć dwie postaci: merytoryczną i formalną. Wykładnia merytoryczna, jak podaje M. Zieliński, to „zespół czynności interpretacyjnych realizowanych zgodnie z przyjętymi w naszej kulturze prawnej regułami. W ujęciu apragmatycznym wykładnia jest wykładnią merytoryczną, jeśli otrzymany rezultat (treść normy) jest wynikiem rzeczywiście poprawnego zastosowania kulturowo zaakceptowanych regul" (M. Zieliński, op. cit., s. 63). 
kładni sentencji orzeczenia $\mathrm{w}$ takim sensie, w jakim posługujemy się terminem "wykładnia” w odniesieniu do przepisów prawnych ${ }^{47}$.

W sentencji tego wyroku trzykrotnie znalazł się zwrot "W zakresie". Na końcu pierwszego z zakresów znalazł się zwrot "a ponadto". W tym miejscu wskazać należy, że „a” jest spójnikiem, który pełni zwykle funkcję tzw. funktora koniunkcji ${ }^{48}$, zaś słowo "ponadto" to partykuła, która nawiązuje do poprzedniego kontekstu i wprowadza zwykle nową informację na omawiany już temat, np. A jest $B$ i posiada cechę $C$, a ponadto jest jeszcze D. Takie rozumienie jednoczesnego zastosowania spójnika "a" z partykułą "ponadto" prowadzi do wniosku, że A jest D niezależnie od tego, czy A jest B i posiada cechę C. Obecnie brzmienie samej sentencji pozwala zatem dojść do wniosku, że art. 1 ust. 1 i 3 ustawy o przekształceniu jest niezgodny z Konstytucją RP w dwóch zakresach, a $\mathrm{w}$ trzecim nie jest niezgodny. Po pierwsze, przedmiot kontroli jest niezgodny w zakresie, w jakim przyznaje uprawnienie do przekształcenia prawa użytkowania wieczystego w prawo własności tym osobom, które nie miały tego uprawnienia przed wejściem w życie nowelizacji z 2011 r. ustawy o przekształceniu. Po drugie, jest niezgodny w zakresie, w jakim odnosi się do (obejmuje) nieruchomości stanowiących własność jednostek samorządu terytorialnego. Po trzecie, nie jest niezgodny w zakresie, w jakim odnosi się do (obejmuje) nieruchomości stanowiących własność Skarbu Państwa.

Efektem takiej ilustracji sposobu "bezpośredniego" rozumienia sentencji orzeczenia TK z 10 marca 2015 r. byłby jednak brak zrozumienia jego intencji, skoro punktem wyjścia miała być, ze względów walidacyjnych, sama tylko sentencja orzeczenia ${ }^{49}$. Taki brak tożsamości - możliwej, jak widać na przykładzie przywołanego orzeczenia Trybunału - pomiędzy rozumieniem komunikatu nadawcy a jego rzeczywistym zrozumieniem może prowadzić do wniosku, że wyrok zakresowy

${ }^{47}$ Byłaby to zatem wykładnia wykładni. Sensownym pytaniem jest jednak, czy takiej wykładni - jako wykładni merytorycznej w procesie stosowania prawa - dokonać może samodzielnie adresat systemu, czy też wykładnia taka powinna zostać przeprowadzona przez ów organ (Trybunał) w ramach przyznanych mu kompetencji wyrażonych w art. 74 ust. 1 dawnej ustawy o TK (byłaby to wówczas wykładnia formalna własnej wykładni formalnej) - aktualnie art. 107 ust. 1 ustawy o TK. Wadą takiego rozwiązania jest jednak to, że tylko uczestnikowi postępowania przysługuje legitymacja złożenia takiego wniosku.

${ }^{48}$ Z. Ziembiński, Logika praktyczna, Warszawa 2013, s. 85-86.

${ }^{49}$ Różnicę występującą pomiędzy rozumieniem a zrozumieniem wyłożył M. Zieliński (op. cit., s. 49-62). 
Trybunału (jak również interpretacyjny) także podlega interpretacji. Problem interpretacji wyroków Trybunału jest złożony. Zaryzykować można stwierdzenie, że taka interpretacja powinna przebiegać według takich samych - lub odpowiednio zastosowanych - reguł i standardów, jakimi prawnicy praktycy kierują się, odtwarzając normy prawne z przepisów prawnych. Argumentem dla takiego stwierdzenia mogą być chociażby względy prakseologiczne, a mianowicie to, że celem zarówno interpretacji tekstu prawnego („nośnika” norm prawnych), jak i interpretacji wyroku zakresowego lub interpretacyjnego Trybunału Konstytucyjnego jest określenie, jaka norma prawna jest normą obowiązującą ${ }^{50}$. Skoro dla interpretacji tekstów prawnych („nośników” norm prawnych) opracowany został zbiór narzędzi służących dekodowaniu z nich norm prawnych i skoro wyrok zakresowy lub interpretacyjny Trybunału Konstytucyjnego uzyskuje (po jego publikacji) moc powszechnie obowiązująca, współwyznacza treść obowiązującej normy prawnej, to dla należytego zrozumienia komunikatu jego nadawcy posłużenie się analogicznymi technikami jest, chociażby ze względów celowościowych, uzasadnione ${ }^{51}$.

Nie ulega wątpliwości, że nie jest możliwe poprzestanie na "bezpośrednim rozumieniu" sentencji wyroków Trybunału. Poszukując dogodnych metod interpretacji, w szczególności wskazać należy w tym miejscu na tzw. derywacyjną koncepcję wykładni prawa - uniwersalistyczną i sensualistyczną koncepcję, która ukształtowała się w latach sześćdziesiątych ubiegłego wieku. Koncepcja ta różni się od tzw. klaryfikacyjnej koncepcji wykładni prawa głównie tym, iż omnia sunt interpretand $a^{52}$. Przedmiotem wykładni - w przypadku pierwszej ze

${ }^{50}$ Jak zasygnalizowano w pierwszej części opracowania, zdaniem autora wyrok zakresowy lub interpretacyjny Trybunału Konstytucyjnego może być uznany, co najwyżej, za powszechnie obowiązującą regułę egzegezy, a dokładniej, regułę interpretacyjną.

${ }^{51}$ Rzecz jasna, przedstawione uwagi odnoszą się także do prostych wyroków Trybunału Konstytucyjnego. Niemniej ich interpretacja, z oczywistych względów, raczej nie będzie nastręczać takich trudności, jakie wystąpić mogą w przypadku wyroków interpretacyjnych lub zakresowych, albowiem wyroki proste są aktami performatywnymi ingerującymi wprost w tekst prawny (tj. w fakt prawotwórczy), czyli w surowiec dla norm prawnych. W efekcie, po ingerencji trybunalskiej, przedmiotem wykładni będzie tekst prawny uwzględniający skutek wyroku prostego. Inaczej rzecz się ma w przypadku wyroków interpretacyjnych lub zakresowych.

${ }^{52}$ Co w przełożeniu na wyrok TK musiałoby oznaczać obowiązek poddania interpretacji nie tylko sentencji orzeczenia, ale i jego uzasadnienia, a wówczas uzasadnieniu można byłoby przyznać taką rolę, jaką nadaje się uzasadnieniu ustaw w procesie wykładni przepisów prawnych. 
wskazanych koncepcji - są określone regułami walidacyjnymi fakty prawotwórcze, a mianowicie teksty prawne. Nie są natomiast z pewnością takimi faktami prawotwórczymi w sensie apragmatycznym wyroki zakresowe lub interpretacyjne Trybunału Konstytucyjnego. Niemniej, zdaniem autora niniejszego opracowania, skoro ostatecznym celem wykładni prawa w ujęciu koncepcji derywacyjnej jest ustalenie treści normy prawnej, to jeśli określone elementy tej normy wyznacza wiążąco akt, jakim jest wyrok Trybunału Konstytucyjnego (pewnego rodzaju komunikat, a takim to komunikatem, tyle że prawodawcy, jest także tekst prawny), nic nie stoi na przeszkodzie, aby przy wykładni sentencji wyroku Trybunału Konstytucyjnego zastosować odpowiednio te narzędzia, jakie opracowano w odniesieniu do wykładni tekstów prawnych.

Gdyby bowiem poprzestać na bezpośrednim rozumieniu wyroku TK, to adresat systemu prawnego ${ }^{53}$ - będący użytkownikiem wieczystym nieruchomości stanowiącej własność jednostki samorządu terytorialnego (niebędący jednocześnie podmiotem, któremu przed wejściem w życie nowelizacji z 2011 r. ustawa nie przyznawała uprawnienia do przekształcenia) - dojdzie do przekonania, że jego prawo użytkowania wieczystego ustanowione na nieruchomość stanowiącą własność jednostki samorządu terytorialnego nie podlega przekształceniu w ogóle. Warto w tym miejscu zaznaczyć, że mowa tutaj o adresacie systemu prawnego, który zarazem: korzysta jedynie z Dzienników Urzędowych, o jakich mowa w art. 190 ust. 2 Konstytucji RP; zna treść sentencji wyroku Trybunału z 10 marca 2015 r.; nie zna komunikatów prasowych związanych z przedmiotowym wyrokiem, ani tym bardziej jego uzasadnienia; zna aktualnie obowiązującą treść ustawy o przekształceniu prawa użytkowania wieczystego w prawo własności; a zatem - mimo niejasności skutków paremii ignorantia iuris nocet oraz ignorantia non excusat - zrobił, obiektywnie rzecz ujmując, wszystko co w jego mocy, by normy prawne regulujące jego sytuację życiową poznać. Tymczasem skutkiem tego wyroku Trybunału nie miał być - jak wynika z jego uzasadnienia - brak możliwości żądania przekształcenia prawa użytkowania wieczystego nieruchomości stanowiących własność jednostki samorządu terytorialnego w prawo własności.

${ }^{53}$ System prawny rozumiany jest jako zbiór norm postępowania obowiązujących $\mathrm{w}$ danym momencie czasu na określonym terytorium. 


\section{Podsumowanie}

Wyrok zakresowy Trybunału omawiany w niniejszym opracowaniu budzi wątpliwości. Przede wszystkim należyte zrozumienie jego sentencji nie jest możliwe bez przeczytania kilkudziesięciostronicowego uzasadnienia. W naszej kulturze prawnej wartościami istotnymi z punktu widzenia praworządności - zarówno formalnej, jak i materialnej ${ }^{54}$ - są między innymi: utrwalona i stabilna koncepcja źródeł prawa; względna stabilność systemu; zapewnienie warunków odnoszących się do samych wytworów faktów prawotwórczych, takich jak: spójność, jasność, komunikatywność, dostateczna precyzja i dostępność do nich adresatów norm prawnych. Zaprezentowany wyrok zakresowy niektórych z tychże cech nie spełnia, wreszcie przerzuca on na adresata systemu prawnego (obywatela) obowiązek zapoznania się nie tylko z dokumentami publikowanymi w dzienniku urzędowym do tego przystosowanym (Dziennik Ustaw Rzeczypospolitej Polskiej lub Dziennik Urzędowy Rzeczypospolitej Polskiej „Monitor Polski”), ale też z uzasadnieniem wyroku, którego "promulgacja” w Zbiorze Urzędowym Orzecznictwa Trybunału Konstytucyjnego de lege lata nie ma takich właściwości i nie rodzi takich skutków prawnych jak ogłoszenie samej sentencji orzeczenia. Niniejszy przypadek wyroku zakresowego - ze względu na generowane przez niego skutki i niebezpieczeństwa - może stanowić dodatkowy argument dla przeciwników tego typu rozstrzygnięć. Na kanwie omawianej sprawy zrodziło się pytanie, jakie są "granice zakresowości" wyroku Trybunału. Wyrok zakresowy miał z założenia być przejawem wstrzemięźliwości w derogacji tych jednostek redakcyjnych tekstu prawnego, których tylko pewien zakres - możliwy do odczytania - nie spełnia

${ }^{54}$ Zasadnicza różnica pomiędzy tymi "typami" praworządności sprowadza się do tego, czy walor praworządności uzyskują te państwa, w których organy państwa działają zgodnie z prawem, czy też miano państwa praworządnego zyskać można, o ile dane prawo spełnia odpowiednie wymogi (czyli państwo ma tzw. „dobre prawo”) i zarazem organy zachowują się zgodnie z nim. Powiada się, że spór pomiędzy zwolennikami przywołanych "opcji" jest nierozstrzygalny przy zastosowaniu metod empirycznych. Autor niniejszego opracowania jest zwolennikiem koncepcji praworządności materialnej, stawiającej dodatkowo "prawu obowiązującemu” pewne wymogi. Katalog tychże wymogów w literaturze jest pokaźny. Wśród nich znajdują się między innymi takie selektywne wartości, jak: "równość praw” i „równość wobec prawa”, zapewnianie realizacji przyznanych praw i obowiązków, „nie niesłuszność" prawa, „należytość" regulacji prawnej i wiele innych. Innym przykładowym naruszeniem praworządności może być niewydanie rozporządzenia wykonawczego, niezbędnego do realizacji normy prawnej (dowolnej wartości) wyrażonej w ustawie, zob. J. Nowacki, Praworzadność, Warszawa 1977, s. 66-68. 
wymogów konstytucyjnych. Owa wstrzemięźliwość osiągnęła jednak nadzwyczajny poziom, gdyż zamiast derogacji prostej określonych przepisów nowelizujących ustawę o przekształceniu posłużono się formułą wyroku zakresowego, wzbudzającą opór niektórych środowisk, i to jeszcze w celu doprowadzenia do odżycia norm prawnych, których moc obowiązująca ustała z dniem wejścia w życie noweli z 2011 r.

Zasadniczym celem niniejszego opracowania było wstępne wskazanie, jakiego rodzaju problemy o charakterze teoretycznoprawnym mogą powstać na gruncie wyroków zakresowych lub interpretacyjnych Trybunału Konstytucyjnego. Zasygnalizowane zagadnienia wymagają dalszych badań - ich całościowe rozważenie wykraczałoby poza ramy niniejszej pracy.

Nie ulega wątpliwości, że w skomplikowanych stanach faktycznych i prawnych Trybunał, chcąc sformułować właściwe brzmienie sentencji swego wyroku zakresowego, stoi przed niełatwym zadaniem. Wynika to nie tylko ze skomplikowania materii, jaką jest prawo, ale przede wszystkim z kwestii zgoła pozaprawnej, jaką jest oczekiwanie społeczne, ażeby najwyższy organ władzy sądowniczej ${ }^{55}$ - którego zadaniem jest kontrola zgodności aktów normatywnych z aktami hierarchicznie wyższymi, podczas gdy nierzadko przyczynami stwierdzanej niekonstytucyjności jest błędna redakcja tekstu prawnego w ramach naruszenia jednej z zasad przyzwoitej legislacji ${ }^{56}$ - sam potrafił się posłużyć odpowiednio i precyzyjnie technikami formułowania swych sentencji.

${ }^{55}$ Istnieje pogląd, że Trybunał w rzeczywistości nie jest organem władzy sądowniczej nawiązujący do dawnej myśli doktrynalnej rozwiniętej na gruncie art. 33a Konstytucji PRL, którego zwolennikiem jest m.in. J. Trzciński - ale raczej organem o szczególnych kompetencjach kontrolnych. Nie jest bowiem sprawowaniem wymiaru sprawiedliwości w rozumieniu art. 177 Konstytucji RP działalność Trybunału, która polega na kontroli hierarchicznej zgodności norm prawnych, zob. M. Florczak-Wątor, op. cit., s. 31-37.

${ }^{56}$ Zasady przyzwoitej legislacji mają szczególne znaczenie w przypadku praw i wolności obywateli. Niejasne i nieprecyzyjne przepisy prawne rodzą niepewność jego adresatów co do treści praw i obowiązków. Jak można zauważyć w orzecznictwie trybunalskim, niejasność lub nieprecyzyjność przepisu stwarzająca dla organów stosujących prawo nazbyt dużą swobodę interpretacji, mogąca prowadzić do wcielania się przez te organy w rolę prawodawcy pozytywnego, oznaczać może przekroczenie pewnego poziomu niejasności przepisów prawnych, stanowiące samoistną przesłankę stwierdzenia ich niezgodności z wyrażoną $\mathrm{w}$ art. 2 Konstytucji RP zasadą państwa prawnego. Zasada ta była już wielokrotnie przedmiotem rozważań Trybunału, m.in. w uchwale z 8 III 1995 r., sygn. W 13/94, OTK 1995, t. I, poz. 21, oraz w wyrokach TK: z 11 I 2000 r., sygn. K 7/99, OTK ZU 2000, nr 1, poz. 2; z 21 III 2001 r., sygn. K 24/00, OTK ZU 2001, nr 3, poz. 51; z 30 X 2001 r., sygn. K 33/00, OTK ZU 2001, nr 7, poz. 217; z 9 IV 2002 r., sygn. K 21/01, OTK ZU 2002, nr 2A, poz. 17; z 24 II 2003 r., sygn. K 28/02, OTK ZU 2003, nr 2A, poz. 13; oraz z 21 II 2006 r., sygn. K 1/05, OTK ZU 2006, nr 2A, poz. 18. 